\title{
Notes on the vocalizations of Brown Scrub-robin (Erythropygia signata)
}

Peter Boesman

In the following we briefly analyze and compare voice of the two races of Brown Scrub-robin (Erythropygia signata). We also try to quantify the extent of any vocal differences using the criteria proposed by Tobias et al. (2010), as a support for taxonomic review. We have made use of sound recordings available on-line from Xeno Canto (XC).

Song is a short phrase of a few sweet pure whistles, often ending with some highe-pitched chirping or buzzing notes. Vocal differences between both races have been described (Clement 2015), with song of race tongensis different in starting with one or more intro notes and more frequently broken in shorter phrases. Also, call of tongensis has a softer single note vs. a series of notes

Some examples of song, illustrated with sonograms:

nominate $(n=10)$

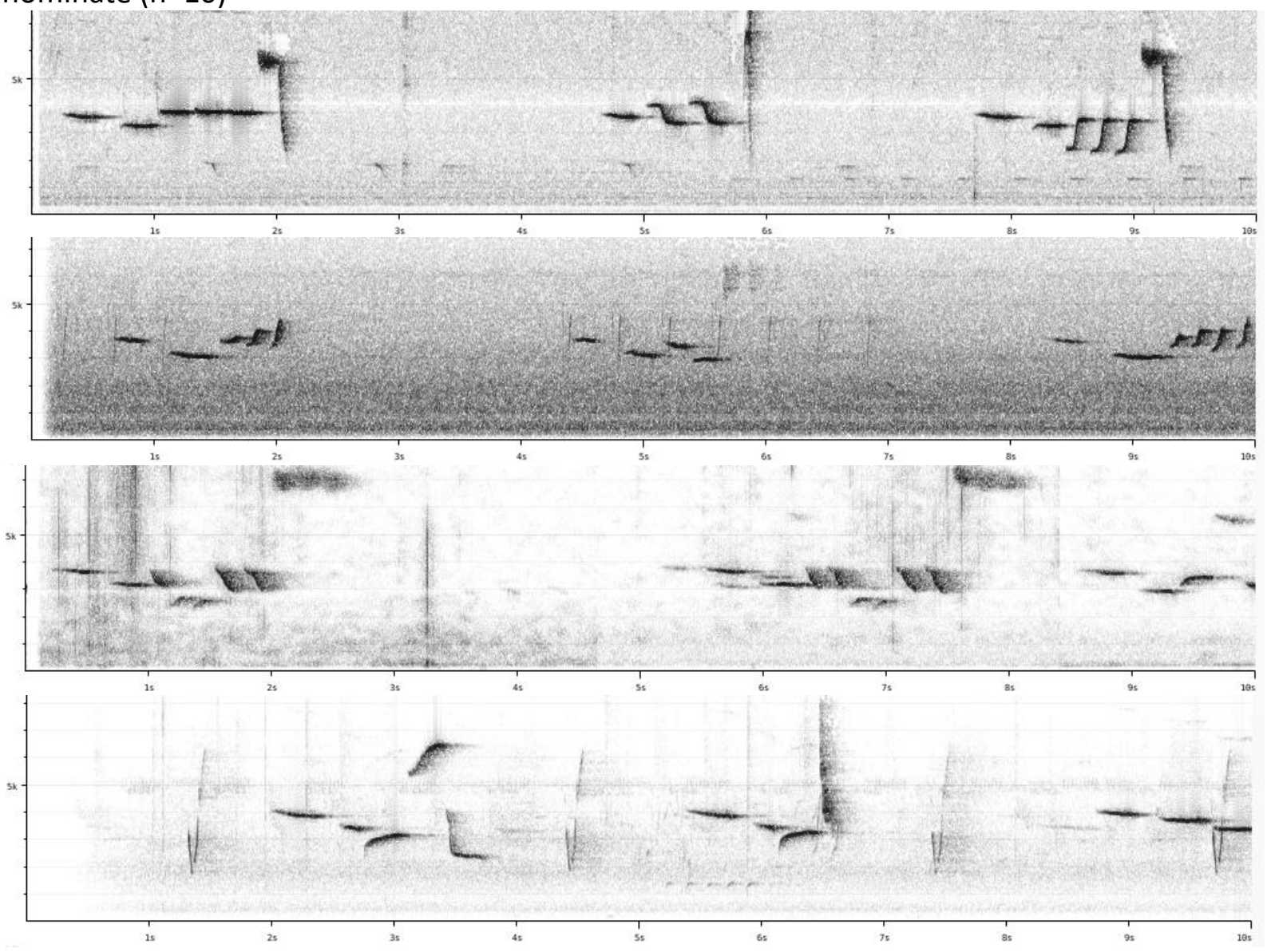



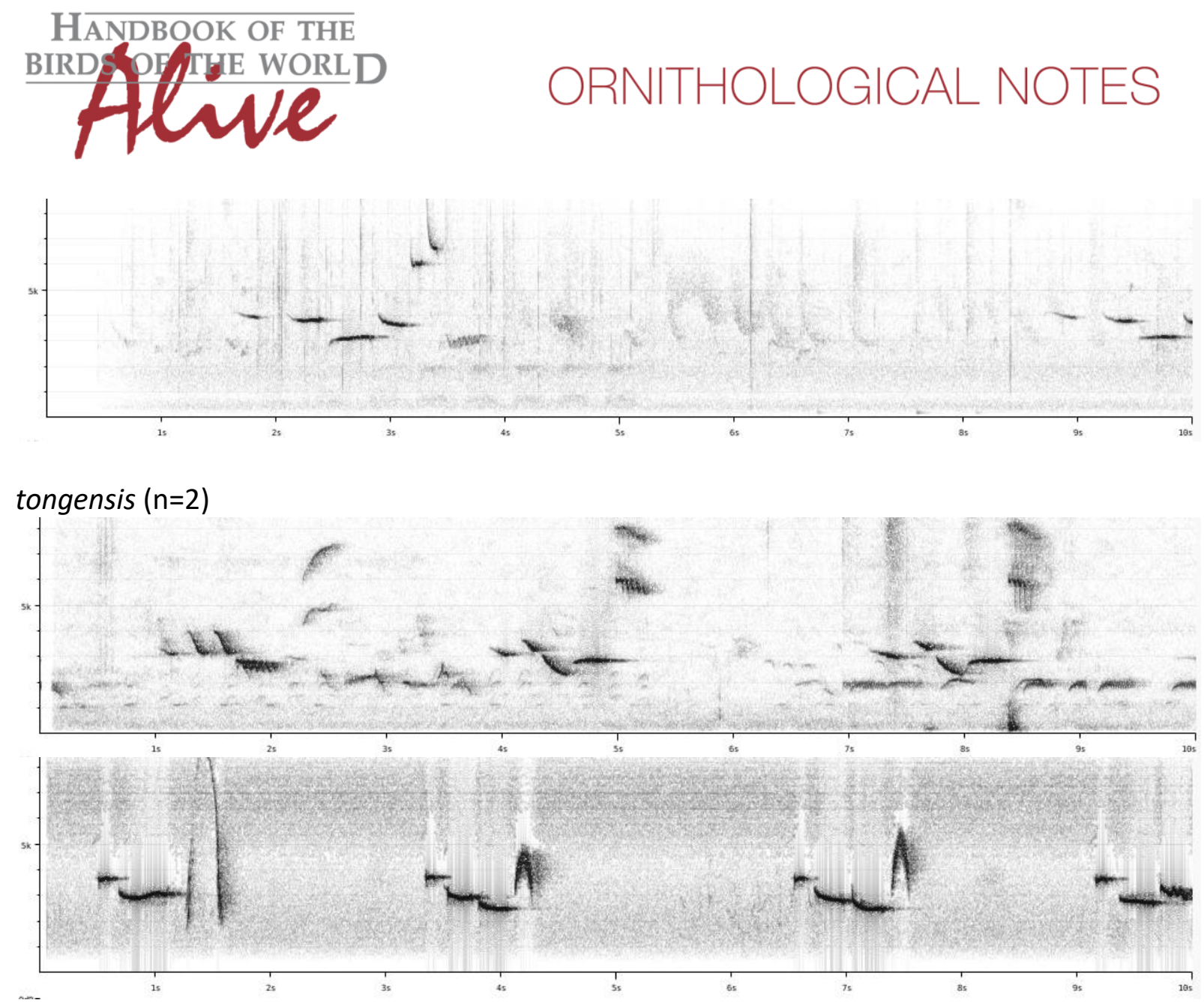

In the above examples, there is no clear difference in song between the two races. Possibly, song phrase of tongensis is slightly shorter on average, but more recordings would be needed to confirm this. The introductory notes to the song (Clement 2015) are apparently not present in the two available examples. Note shapes seem to be rather similar (the overslurred end note in one example of tongensis could be unique to that race, but obviously this would have to be proven by many more recordings).

No recordings available of call notes of tongensis.

Based on the few available recordings (more needed for tongensis), there are no obvious vocal differences.

This note was finalized on 5th May 2016, using sound recordings available on-line at that moment. We would like to thank in particular the sound recordists who placed their recordings for this species on XC: Patrik Åberg, Peter Boesman, Alan Collett, Tim Cockcroft, Christoph Groenewald, Charles Hesse, Niall Perrins, Lynette Redman and David Winter. 


\section{References}

Clement, P. \& Rose, C. (2015). Robins and Chats. Helm Identification Guides. Christopher Helm. London.

Tobias, J.A., Seddon, N., Spottiswoode, C.N., Pilgrim, J.D., Fishpool, L.D.C. \& Collar, N.J. (2010). Quantitative criteria for species delimitation. Ibis 152(4): 724-746.

\section{Recommended citation}

Boesman, P. (2016). Notes on the vocalizations of Brown Scrub-robin (Erythropygia signata). HBW Alive Ornithological Note 313. In: Handbook of the Birds of the World Alive. Lynx Edicions, Barcelona. (retrieved from http://www.hbw.com/node/1251831 on 18 October 2016). 